\title{
Peran Visi Bagi Kelanggengan Bisnis Keluarga
}

\author{
Andreas Heryjanto \\ Magister Manajemen, Universitas Bunda Mulia \\ email: aheryjanto@bundamulia.ac.id
}

\begin{abstract}
Business longevity is one of the goals of a family business, where business is expected to last for a long time, whether in the hands of family members or handled by professionals. The longevity of a family business is influenced by the values in it. Values that are needed in the family business are usually embedded in a vision. In vision contained the values, beliefs, principles, and binding promises, which characterize a family business.

The embodied vision by all owners and employees is able to satisfy customers, which ultimately perpetuates a family business. In order to realize the sustainability of the family business, integration between family harmony, tolerance of differences, participation and openness among stakeholders are needed.

Based on the business vision, the factors such as competitive value proposition, distinctive capabilities, dynamic capabilities, trust and commitment are created, which are useful for achieving the longevity of a family business.
\end{abstract}

\begin{abstract}
ABSTRAK
Kelanggengan bisnis merupakan salah satu tujuan bisnis keluarga, di mana bisnis diharapkan dapat berlangsung dalam waktu yang lama, entah di tangan anggota keluarga ataupun ditangani oleh profesional. Kelanggengan suatu bisnis keluarga dipengaruhi oleh nilai-nilai yang ada di dalamnya. Nilai-nilai yang sangat dibutuhkan dalam bisnis keluarga biasanya terkandung dalam suatu visi. Di dalam visilah terkandung nilai-nilai, keyakinan, prinsip, dan janji yang mengikat, yang memberikan ciri khas suatu bisnis keluarga.

Pengejawantahan visi dengan tepat oleh seluruh pemilik dan karyawan mampu memuaskan pelanggan, yang akhirnya melanggengkan suatu bisnis keluarga. Untuk mewujudkan tercapainya kelanggengan bisnis keluarga tersebut, diperlukan keterpaduan antara harmoni keluarga, toleransi terhadap perbedaan, partisipasi dan keterbukaan di antara pemangku kepentingan.

Bersumber dari visi bisnis terciptalah faktor-faktor janji nilai bersaing, kemampuan unik, kemampuan dinamis, kepercayaan dan komitmen, yang bermanfaat untuk tercapainya kelanggengan suatu bisnis keluarga.
\end{abstract}

Key words : Business longevity, vision, trust and commitment 


\section{LATAR BELAKANG}

Keberlanjutan bisnis keluarga meliputi kelanggengan (longevity) bisnis dilihat dari dimensi waktu maupun continuity yaitu keberaturan peralihan lintas generasi dalam rentang waktu yang panjang (Heryjanto, 2016). Dengan demikian, kelanggengan bisnis (business longivity) merupakan salah satu tujuan bisnis keluarga. Bisnis diharapkan dapat berlangsung dalam waktu yang lama, entah di tangan anggota keluarga ataupun ditangani oleh profesional.

Menurut Tàpies dan Moya (2012), kelanggengan suatu bisnis keluarga dipengaruhi oleh nilai-nilai yang ada di dalamnya. Nilai-nilai yang sangat dibutuhkan dalam bisnis keluarga biasanya terkandung dalam suatu visi. Di dalam visilah terkandung nilai-nilai, keyakinan, prinsip, dan janji yang mengikat, yang sangat mewarnai kehidupan suatu bisnis keluarga. Oleh karena itu, iklim bisnis yang produktif, etis dan bermoral, serta yang mengarah pada kelanggengan untuk jangka waktu yang panjang sangat dipengaruhi oleh visi bisnis tersebut. Visi yang diyakini dan diejawantahkan oleh seluruh pemangku kepentingan bisnis tersebut memungkinkan bisnis keluarga bertahan di tengah persaingan bisnis yang semakin kompleks dan kompetitif. Dari visilah, pimpinan bisnis menentukan tujuan bisnis jangka panjang berikut strateginya, agar bisnis keluarga langgeng untuk jangka waktu yang panjang.

Salah satu bisnis keluarga yang membuktikan kedahsyatan visi bagi kelanggengan bisnisnya adalah Bandeng Juwana "Elrina" (selanjutnya disebut Bandeng Juwana). Bandeng Juwana merupakan bisnis keluarga yang menjual makanan oleh-oleh khas Semarang seperti Bandeng Duri Lunak, Wingko, Moaci, Lunpia, dan makanan khas daerah lainnya. Bisnis keluarga Bandeng Juwana yang saat ini telah menjadi salah satu icon Kota Semarang tersebut diawali tahun 1981 oleh dr. Daniel dan istrinya. Sebagai pemain kedelapan di bisnis bandeng saat itu, Bandeng Juwana harus berjuang keras mensejajarkan diri dengan pemain lama. Mengawali dengan berbisnis di emperan rumahnya yang hanya mampu menjual beberapa ekor bandeng, saat ini telah berkembang pesat dengan beberapa outlet dan tempat produksi yang mempekerjakan +/- 1.000 karyawan. Visi bisnis keluarga yang merupakan buah pemikiran dari dr. Daniel sebagai pendiri bisnis bersama keluarga dan konsultan bisnisnya, telah menjadikan bisnis keluarganya mampu 
bertahan bahkan berkembang sampai saat ini. Visi Bandeng Juwana "Wujud kasih dan berkat Tuhan serta pengamalan kasih" mampu diejawantahkan menjadi keunggulan bisnisnya.

Penelitian ini terfokus pada peranan visi bisnis keluarga yang mampu mempertahankan kelanggengan bisnis keluarga "Bandeng Juwana" di tengah persaingan bisnis oleh-oleh yang sangat kompetitif di Kota Semarang.

\section{MASALAH PENELITIAN}

Masalah penelitian ini adalah bagaimana Bandeng Juwana mampu mempertahankan kelanggengan bisnisnya di tengah persaingan bisnis oleh-oleh di Kota Semarang yang semakin kompetitif, dengan persoalan-persoalan penelitian :

- Bagaimana visi mampu melanggengkan bisnis Bandeng Juwana ?

- Faktor-faktor apa saja yang terbentuk dari visi tersebut?

\section{TUJUAN PENELITIAN}

Adapun tujuan dari penelitian ini adalah :

- Memberikan gambaran bagaimana peranan visi dalam melanggengkan bisnis Bandeng Juwana

- Memberikan gambaran faktor-faktor apa saja yang terbentuk dari visi tersebut

\section{TINJAUAN PUSTAKA}

\section{Kelanggengan bisnis}

Kelanggengan menyangkut kecocokan dan ketahanan bisnis keluarga ke masa depan dilihat dari dimensi waktu, entah di tangan keluarga atau profesional (Heryjanto, 2016). Untuk mencapai kelanggengan, penerus bisnis harus berpikiran terbuka dan obyektif. Suatu bisnis keluarga dituntut lebih kreatif saat menghadapi dinamika pasar dan persaingan yang semakin ketat (Susanto et. al., 2007). Penerus bisnis dapat melanjutkan atau menghentikan strategi, identitas maupun produk / bisnis inti, dengan tetap mempertahankan nilai-nilai positif yang telah dibuat oleh generasi pendahulu agar bisnis dapat berlangsung untuk jangka waktu yang panjang. Nilainilai tersebut dapat dipakai sebagai faktor pendorong bagi kelanggengan bisnis keluarga, berupa : keinginan untuk melihat 
bisnis bertumbuh dan berkontribusi bagi masyarakat, menyediakan tempat kerja yang nyaman, dan menyediakan pengalaman, kesempatan serta tanggung jawab profesional yang menantang bagi anggota-anggota keluarga (Ward, 2004:106). Dengan demikian, generasi penerus bisnis harus tetap memelihara semangat kewirausahaan (spirit of enterprise) yang telah dirintis oleh generasi terdahulu, dengan mendefinisikan kembali bisnis yang dipercayakan kepadanya.

Namun demikian, bisnis rintisan awal tidak harus dipertahankan apabila sudah tidak sesuai dengan lingkungan bisnisnya. Penerus bisnis memiliki kebebasan untuk beradaptasi dan berkembang, mengakuisisi perusahaan lain, termasuk menjual atau menutup bisnis awal ketika tidak lagi menguntungkan dengan tetap mempertahankan nilai-nilai yang telah dirintis oleh pendiri.

\section{Visi}

Visi sangat mewarnai kehidupan suatu bisnis keluarga, karena di dalamnya terkandung suatu keyakinan, nilai-nilai, prinsip, dan janji yang mengikat. Seperti yang dinyatakan oleh Yoeli and Berkovich (2010) : “Vision as a means of guiding organizational activity, very often in the form of a "credo" or formal doctrine". Visi bersifat holistik, yang memiliki sumber kekuatan energi yang penuh untuk mengarahkan tujuan yang diimpikan suatu bisnis (Morden, 1997). Pimpinan bisnis memiliki tanggung jawab khusus untuk mengomunikasikan visi bersama di lingkungan internalnya, dengan menerapkan iklim bisnis yang etis, bermoral, serta menumbuhrasakan ke arah tujuan yang ingin dicapai (Conte, Siano, dan Vollero, 2017). Dengan nilai-nilai mulia yang dikandung di dalam visi bisnis itulah akan mengarah pada kelanggengan bisnis, seperti yang diungkapkan oleh Tàpies dan Moya (2012), yaitu : “Quality, honesty and hard work are values that highly contribute to company longevity" Visi bisnis akan mewarnai, mengukir, dan membentuk profil sumberdaya unggul, yang menjadi faktor penting untuk mencapai kelanggengan bisnis keluarga.

Visi yang efektif adalah yang mampu memberikan inspirasi, menantang dan dapat dipercaya, sehingga mendorong setiap individu di dalam bisnis tersebut untuk melakukan yang terbaik. Visi yang demikian akan membangkitkan komitmen dari seluruh karyawan yang terlibat (Susanto et al.,2008), karena : 
- Seluruh karyawan memiliki tujuan dan perasaan bersama

- Lebih banyak tanggung jawab yang bisa didelegasikan

- Mendorong kreativitas, sehingga banyak ide yang disumbangkan

\section{Janji Nilai Bersaing}

Kemampuan mengembangkan keunggulan menjadi relevan untuk mengatasi ketatnya persaingan akibat perubahan selera konsumen yang begitu cepat. Janji nilai bersaing (competitive value proposition) adalah segugus barang fisik, layanan dan / atribut tambahan unggul yang sesuai dengan kebutuhan pelanggan (De Wit dan Meyer, 2005). Menurut Carpenter dan Sanders (2009), produk dan layanan yang berkualitas diharapkan mendukung kelanggengan bisnis keluarga ke masa depan. Banyaknya item produk yang ditawarkan, produk berkualitas, layanan prima, tempat strategis, strategi harga yang tepat, serta promosi yang menarik, semuanya dilakukan dalam upaya menciptakan keunggulan tersebut. Produk dan layanan yang ditawarkan oleh bisnis keluarga tersebut haruslah mempunyai nilai yang lebih tinggi bagi konsumen / pelanggan dibandingkan dengan alternatif yang disediakan oleh pesaing (De Wit dan Meyer, 2005). Hal itu dapat dilakukan dengan mengoptimalkan sumber-sumber daya yang dimiliki suatu bisnis keluarga agar ditemukan cara-lebih-baik (better) atau cara-berbeda (different) dalam menjalankan aktivitas yang sama (Carpenter dan Sanders, 2009).

\section{KEMAMPUAN UNIK DAN KEMAMPUAN DINAMIS}

Resource-based View

$(\mathrm{RbV})$

menjelaskan tentang sebuah paket sumber daya (resources), keahlian (skills) dan kemampuan (capabilities) (Warnerfelt, 1984) yang melekat dalam bisnis keluarga untuk memperoleh keunggulan-bersaing (competitive advantage). Tokarczyk et. al. (2007) mengungkapkan bahwa RbV menganggap suatu perusahaan sebagai sumber daya (organizational competencies) yang tertanam dalam proses internal, sumber daya manusia atau aset tanwujud lainnya dapat memberikan keunggulan-bersaing bagi perusahaan dalam situasi tertentu. Agar suatu bisnis mampu berkompetisi dalam jangka panjang, sumber daya yang dimilikinya harus bercirikan VRINE, yaitu : value, rarity, inimitability, nonsubstitutability (Barney, 1991 ; Hooley, Piercy dan Nicoulaud, 2012:136) dan exploitability (Carpenter dan Sanders, 2009:103). Suatu 
bisnis yang memiliki sumberdaya bercirikan VRINE tersebut disebut memiliki kemampuan unik. Kemampuan unik adalah kemahiran meracik assets yang menciptakan suatu keunikan untuk perusahaan (Ihalauw, 2013).

Suatu bisnis yang memiliki sumber daya yang bernilai (valuable resources), memampukannya untuk mengimplementasikan strategi-strateginya secara efektif dan efisien (Barney, 1991), Dengan sumber daya yang bercirikan rarity, memungkinkan suatu bisnis menciptakan kelangkaan relatif terhadap suatu permintaan. Dengan demikian, menurut Carpenter dan Sanders (2009) suatu bisnis yang memiliki sumber daya yang bercirikan valuable dan rarity akan terjamin keunggulannya selama pesaing belum memilikinya atau mampu menemukan pengganti yang mirip. Salah satu cara yang dapat dilakukan suatu bisnis agar sumberdaya yang dimilikinya tetap valuable dan rarity (Hooley, Piercy dan Nicoulaud, 2012) yaitu melalui tacitness, yaitu keahlian dan pengetahuan tanwujud yang dihasilkan dari belajar dan melakukan.

Selama pesaing belum berhasil memperoleh sumber daya yang valuable dan rare dengan cepat, atau diperolehnya dengan harga lebih mahal, maka kriteria inimitability sempurna terpenuhi dan selama pesaing tidak bisa mendapatkan manfaat yang sama dengan menggunakan kombinasi sumber daya bernilai yang berbeda, tercapailah kriteria nonsubstitutability sempurna. Untuk mewujudkan itu semua, suatu bisnis harus memiliki kemampuan untuk mengeksploitasinya (exploitability) atas sumber daya yang dimilikinya agar memiliki keunggulan bersaing.

Namun demikian, suatu bisnis tidak mungkin mampu mempertahankan kemampuan unik sumberdaya yang dimilikinya selamanya. Untuk mempertahankannya, harus tetap memperhatikan pengaruh pasar yang dinamis dalam upaya memperbaharui sumber daya dan mengembangkan new capabilitiesnya (Carpenter dan Sanders, 2009:108; Hooley, Piercy dan Nicoulaud 2012:136). Dengan menyesuaikan diri dengan kondisi lingkungan eksternal yang dinamis, suatu bisnis harus memperbaharui dan mengembangkan sumberdaya yang dimilikinya. Kemampuan baru (kemampuan dinamis) dapat diperoleh melalui proses pembelajaran (learning), inovasi dan kreativitas yang melibatkan 
seluruh sumber daya yang dimiliki bisnis tersebut. (Carpenter Sanders, 2009; Hooley, Piercy dan Nicoulaud, 2012). Kemampuan dinamis (dynamic capabilities) adalah kemahiran perusahaan untuk memodifikasi dan merevisi sumberdaya dan keahliannya sesuai dengan perubahan lingkungan (Carpenter dan Sanders, 2009).

\section{Kepercayaan (trust) dan Komitmen}

Menurut Lee (2004), keunikan bisnis keluarga dalam aras tertingginya adalah kepercayaan (trust) dan komitmen. Kedua faktor itu mutlak diperlukan, karena menurut Grote (2003) bahwa kesuksesan bisnis keluarga tidak dapat dilepaskan dari family rivalries. Bahkan menurut Freud (Carlock dan Ward, 2001) “intensity of family and work relationship is created by conflicts between 'lieben und arbeiten' (love and work)" yang sangat mudah memicu konflik di antara keluarga dan bisnis.

Kepercayaan (trust) adalah keyakinan seseorang tentang ketulusan pihak lain terhadap kepentingan bersama, sedangkan komitmen adalah kesediaan seseorang untuk secara sukarela mengikatkan diri pada tujuan bersama (Ihalauw, 2013). Kepercayaan akan muncul dari pengalaman individu dalam bisnis dan keluarga, dengan bekerja bersama untuk merencanakan atau memecahkan masalah serta mengembangkan aturan-aturan keluarga yang adil dan menerapkannya secara konsisten untuk seluruh anggota keluarga (Carlock dan Ward, 2001:11). Bisnis keluarga cenderung stabil, konservatif, dan menjadi loyal terhadap visi, misi dan nilainilai pendiri karena keluarga memiliki komitmen jangka panjang terhadap bisnisnya (Susanto et al., 2008). Namun demikian, komitmen bukan hanya untuk penerus bisnis dan karyawan, karena komitmen pendirilah yang menyebabkan bisnis bisa terus bertahan. Oleh karena itu, penting untuk membangun komitmen bisnis bagi keluarga serta membuat perencanaan guna mewujudkan komitmen tersebut.

\section{METODE PENELITIAN}

Penelitian ini menggunakan metode penelitian kualitatif. Desain yang digunakan dalam penelitian ini adalah studi kasus. Dengan desain studi kasus ini, diharapkan dapat diperoleh gambaran secara cermat terhadap gejala-gejala dan fakta-fakta aktual yang tidak dapat dipisahkan dari latar alamiahnya (Creswell, 2015; Ghony dan Fauzan, 2012). Dalam 
studi kasus ini, yang dipakai adalah kasus tunggal, yaitu bagaimana peran visi bisnis dalam mempertahankan kelanggengan bisnis Bandeng Juwana.

Wawancara mendalam terhadap beberapa informan kunci, studi dokumentasi, serta observasi pasif dengan waktu yang berbeda-beda, diharapkan tercapai triangulasi dalam penelitian ini. Wawancara dilakukan kepada informan kunci yang bersedia diwawancarai secara langsung yaitu Daniel (pendiri bisnis) dan Arif (menantu yang aktif menangani bisnis sehari-hari). Observasi dilakukan dengan cara pengamatan, dengan tidak terlibat dalam kegiatan-kegiatan subyek penelitian dan tidak berinteraksi dengan mereka secara langsung. Observasi dilakukan hanya pada hal-hal yang terkait dengan topik yang diteliti atau yang sangat relevan dengan data yang dibutuhan. Sedangkan studi dokumentasi diperoleh dari dokumen (buku harian, surat-surat, aturan, memo), foto, serta informasi yang tersedia di internet.

\section{HASIL DAN PEMBAHASAN}

Dari hasil wawancara mendalam, observasi dan dokumentasi yang diperoleh, terjawablah persoalan-persoalan penelitian yang terangkum dalam beberapa bagian berikut ini :

- PERANAN VISI DALAM MELANGGENGKAN BISNIS

\section{BANDENG JUWANA}

Visi merupakan fondasi bisnis keluarga, karena di dalamnya terkandung suatu keyakinan, nilai-nilai, prinsip, dan janji yang mengikat. Visi yang diyakini oleh seluruh pemangku kepentingan dan diejawantahkan dengan tepat akan menghasilkan kekuatan untuk melanggengkan suatu bisnis keluarga. Hal ini terwujud dengan sempurna di bisnis keluarga Bandeng Juwana. Seperti yang dinarasikan dengan gamblang oleh pendiri Bandeng Juwana, dr. Daniel, demikian :

"Visi / misinya : kasih sama kreatif (kasih dan kreatif)

Saya ngajari (mendidik) pegawai saya :

'Kowe harus kasih sama kreatif' (kamu harus berbuat kasih dan kreatif)

Suatu ketika ada rombongan datang satu bus, tour-leadere (tourleadernya) turun masuk sini, tanya ..... (nama pesaing utamanya) di mana? Ooo di ...... (menunjukkan nomor yang dituju) Mbok saya dianterken, dianterken sama pegawai saya"l

\footnotetext{
${ }^{1}$ Wawancara dengan dr. Daniel, tanggal 27 Januari 2018
} 
(tolong saya diantarkan, terus diantarkan oleh pegawai saya) Masuk ke sana terus dianterken (diantarkan) semua. Tinggal pulang

Kira-kira setengah jam rombongan itu ke sini semua,

karena di sana digetak sama (dibentak oleh) kasirnya Tour-leader bilang : Yuk pindah wae (aja ke) Bandeng Juwana. Bandeng Juwana luwih apik wong e (lebih baik orangnya)

Pada waktu mendengar kejadian tersebut, sebenarnya dr. Daniel dalam hati mengatakan bahwa karyawannya bertindak bodoh. Bagaimana mungkin calon pembeli menanyakan ke pesaing, malahan diberi tahu dan bahkan diantar sampai ke tempat yang dituju. Tetapi, dia tidak berani mengatakan terus terang ke pegawai tersebut, karena bagaimanapun juga yang mengajarkan tentang kasih adalah dirinya sendiri. Dan itu berarti pegawai tersebut sedang mengamalkan visi yang diajarkannya. Akhirnya, dr. Daniel baru sadar bahwa kasih itu luar biasa. Kejadian itu memungkinkan konsumen bisa merasakan betapa primanya layanan yang diberikan kepada mereka, sehingga mereka sangat terkesan dengan tindakan pegawainya tersebut. Justru di sinilah pengejawantahan visi dengan tepat oleh seluruh pemilik dan pegawai mampu memuaskan pelanggan, yang akhirnya melanggengkan bisnis keluarga tersebut.

Walaupun untuk mewujudkan visi tersebut terkadang terasa merugikan bisnis sendiri, tetapi hal tersebut tetap harus dilakukan. Hal ini juga diyakini oleh pendiri Bandeng Juwana di dalam menjalankan bisnisnya, seperti yang diungkapkan berikut ini :

"Seperti orang parkir di sini, tukang parkir ndak boleh tanya (tidak boleh bertanya) mau beli di mana.

Kalau parkir di mana-mana ada tulisannya:

parkir khusus untuk toko .... saya punya ndak (tidak) Malah kencing (buang air kecil) tempat saya, kan bersih Tapi buat saya ndak (tidak) masalah, karena saya punya toko itu merasakan bahwa narik (menumbuhkan minat) orang masuk ke toko itu sukar bagaimana orang bisa laku kalau orang itu tidak masuk toko Jadi dia masuk sini duduk, ndak (tidak) beli saya sudah untung Dia tahu di sini ada ini ... dia tahu. suk ben nek butuh itu ke sini (lain kali kalau membutuhkan itu, dia akan ke sini) Nunut ke toilet ya nggak papa (Numpang ke toilet ya tidak apaapa) 
Buat saya ndak (tidak) masalah",2

Masalah utama di kawasan tersebut adalah masalah lahan parkir yang terbatas. Para pesaing menerapkan parkir untuk pembeli di tokonya, sedangkan Bandeng Juwana justru membebaskan lahan parkirnya dipakai oleh yang membutuhkan, termasuk pengunjung yang hanya melihat-lihat saja. Bahkan dr. Daniel menganggap suatu keuntungan apabila orang mau parkir dan datang ke tokonya walaupun tidak membeli sama sekali. Menurutya, paling sukar meminta konsumen untuk mau masuk ke toko. Pada waktu konsumen sudah masuk toko, biasanya mereka akan dengan mudah dipengaruhi oleh suasana toko dan tidak terlalu mempermasalahkan harga lagi. Selain itu, keuntungan lainnya apabila mereka puas dengan layanan yang diberikan, mereka tidak segan-segan untuk merekomendasikan ke orang lain, sehingga terjadilah word of mouth (getok tular). Bagaimanapun tindakan yang dilakukannya selama ini merupakan pengejawantahan visi yang

\footnotetext{
${ }^{2}$ Wawancara dengan dr. Daniel, tanggal 27 Januari 2018
}

diyakininya yaitu kasih. Hal itu terbukti justru menguntungkan bagi kelangsungan hidup bisnis tersebut.

Selanjutnya untuk mewujudkan visi tersebut harus memberikan manfaat kepada masyarakat pada umumnya dan konsumen pada khususnya. Seperti yang diungkapkan oleh dr. Daniel berikut ini

"Seringkali mahasiswa itu datang dari Yogya, dari mana-mana, Ngajari bikin bandeng (melatih cara mengolah bandeng) dan kita itu biasanya banyak sekali mahasiswa yang praktek di sini ndak ada satupun yang kita umpetin. Sak bumbunya kita ...... (Tidak satupun yang kita sembunyikan. Seluruh bumbunya kita berikan)

Untung saya tuh kalau ngajari koyo ngono, itu saya promosi

(Keuntungan saya kalau mengajarkan seperti itu, itu saya promosi)

Buat saya mengutungkan karena banyak yang tahu Bandeng Juwana Hampir tiap minggu pasti ada"3

Bagi dr. Daniel, dengan mengejawantahkan visinya berarti juga menguntungkan bagi Bandeng Juwana. Orang semakin tahu tentang aneka ragam oleh-oleh produk bandeng dan Kota Semarangpun dikenal dengan

\footnotetext{
${ }^{3}$ Wawancara dengan dr. Daniel, tanggal 27 Januari 2018 dan 17 Maret 2018
} 
oleh-oleh produk bandengnya. Dengan demikian, banyak wisatawan yang mampir di kota Semarang akan mencari oleh-oleh bandeng sebagai oleh-oleh khas kota Semarang. Dengan mengajarkan tentang seluk beluk mengolah bandeng tersebut, juga merupakan promosi yang secara tidak langsung akan membentuk loyalitas pelanggan. Para mahasiswa yang pernah diajarkan tentang bandeng tersebutpun tahunya kalau membeli produk bandeng di Bandeng Juwana, termasuk merekomendasikan ke teman-temannya pun di Bandeng Juwana.

Di samping itu, pengelolaan Bandeng Juwana yang dilakukan bersama-sama oleh generasi pertama dan kedua memerlukan keterpaduan antara harmoni keluarga, toleransi terhadap perbedaan, partisipasi dan keterbukaan, agar kelanggengan bisnis keluarga tercapai. Visi yang dimiliki dan diejawantahkan dengan sempurna oleh keluarga Bandeng Juwana tersebut mampu menjaga harmoni keluarganya, seperti yang diungkapkan oleh Arif berikut ini :

"Dengan kasih itu .... Meniadakan banyak perbedaan.... Beda karakter beda sifat
Dengan landasaran kasih itu yang ndak (tidak) mungkin jadi mungkin Dengan tetap profesional" 4

\section{FAKTOR-FAKTOR YANG \\ TERBENTUK DARI VISI}

Visi yang diyakini dan diejawantahkan di dalam bisnis keluarga akan memberikan dampak yang luar biasa, yang berpengaruh terhadap kelangsungan bisnis keluarga tersebut. Hal ini disebabkan visi bisnis tersebut akan membentuk beberapa faktor yang bermanfaat di dalam persaingan, yaitu :

\section{JANJI NILAI BERSAING}

Janji nilai bersaing (competitive value proposition) terwujud apabila barang/jasa serta layanan yang ditawarkan mampu memberikan solusi yang lebih baik daripada pesaing. Di sinilah pentingnya peran visi untuk mewujudkannya. dr. Daniel menyadari bahwa Bandeng Juwana bukanlah pemain pertama di bisnis tersebut, maka menawarkan solusi yang lebih baik atas kebutuhan pelanggan merupakan faktor yang penting. Dengan mempelajari pola konsumsi pelanggan yang sebagian besar membeli untuk oleh-oleh,

\footnotetext{
${ }^{4}$ Wawancara dengan Arif, tanggal 13 Oktober 2018
} 
dikaitkan dengan jadwal transportasi pesawat udara dan kereta api saat itu, maka Bandeng Juwana saat merintis bisnis membuka layanannya lebih awal dibanding pesaing.

“.... jam 08.00, istri saya buka jam 07.00 di emperan” kata dr. Daniel. ${ }^{5}$

("..... (pesaing utama membuka tokonya) jam 08.00, istri saya membuka toko

jam 07.00 di teras rumah" kata dr. Daniel)

Ditambahkan pula oleh Arif :

\section{"Toko lain lebaran tutup, kami buka"6}

Berbisnis lebih awal dari pesaing utama ternyata berdampak signifikan pada keberhasilan mempertahankan pelanggan dan menarik konsumen yang baru. Termasuk pula membuka toko saat pesaing tutup. Di bisnis oleh-oleh, pelanggan tidak boleh dikecewakan yang diakibatkan karene kecele, sehingga tidak bisa mendapatkan produk yang ingin dibawa tepat pada waktunya.

Selain itu, produk yang ditawarkan oleh Bandeng Juwana relatif paling

\footnotetext{
${ }^{5}$ Wawancara dengan dr. Daniel, tanggal 27 Januari 2018

${ }^{6}$ Wawancara dengan Arif, tanggal 13 Oktober 2018
}

lengkap dibanding para pesaingnya. Bandeng Juwana senantiasa berusaha untuk memenuhi tokonya dengan aneka ragam oleh-oleh yang dibutuhkan oleh pelanggan dan pelancong yang gemar membawa oleh-oleh khas daerah.

"Toko harus semepek (selengkap)
mungkin, tiap kali harus ada yang
baru.
Di sini ndak (tidak) ada yang jual
tongki (hasil persilangan bebek
jantan dan
entok betina)
Ya itu memang tidak besar ya ....
tapi buat saya itu ....... sangat
penting itu lengkap
Jadi orang ke sini apa saja ada”
kata dr. Daniel"

Menjadi toko oleh-oleh serba ada menjadikan Bandeng Juwana menjadi jujugan utama para pemburu oleh-oleh khas daerah. Dengan terbatasnya lahan parkir, pembeli cenderung efisiensi waktu di satu tempat untuk mendapatkan berbagai jenis oleh-oleh yang dibutuhkan.

Selain itu, Bandeng Juwana juga memahami kebutuhan pelanggan untuk mencoba produk baru, sehingga disediakanlah sampel gratis untuk semua jenis roti yang baru dibuatnya.

\footnotetext{
${ }^{7}$ Wawancara dengan dr. Daniel, tanggal 27 Januari 2018
} 
Dari sampel inilah, biasanya muncul produk-produk baru andalan yang akan menambah omzet perusahaan. Selain itu dengan adanya sampel tersebut, akan menyempurnakan produk tersebut dari saran dan kritikan konsumen yang mencobanya. Penyediaan sampel inilah menjadi faktor janji nilai bersaing yang utama dalam upaya memenuhi kepuasan konsumen.

"Jadi roti semua kasi (diberikan) sample semua” kata dr. Daniel ${ }^{8}$

\section{KEMAMPUAN UNIK (DISTINCTIVE CAPABILITIES)}

Kemampuan unik yang dimiliki oleh suatu bisnis memudahkan pelanggan untuk membedakannya dari pesaing. Ada ciri khas yang dimiliki bisnis tersebut yang tidak dimiliki oleh pesaingnya. Bersumber dari visi bisnis Bandeng Juwana, terciptalah aneka bandeng yang tidak dilakukan oleh pesaingnya.

"Masakan bandeng termasuk roti yang isinya bandeng .....

Itu semua 78 macem" kata $d r$. Daniel $^{9}$

\footnotetext{
${ }^{8}$ Wawancara dengan dr Daniel, tanggal 27 Januari 2018

${ }^{9}$ Wawancara dengan dr. Daniel, tanggal 27 Januari 2018
}

Arif, salah satu penerus bisnis Bandeng Juwana, menambahkan demikian :

“Ada sesuatu yang beda dari toko yang lain

variasi dari bandeng ini sangat banyak dibanding yang lain Kepengin (inginnya) yang dibawa dari Semarang yang ciri khasnya dari bandeng Kalau sini ada bandeng duri lunak, otak-otak bandeng biasa ....

Kita ada bandeng teriyaki, ada sate bandeng, ada aneka pepes nasi goreng bandeng, nasi bakar bandeng tahu bakso jadi tahu bandeng, sate bandeng ada, bergedel bandeng "10

Dengan bahan dasar ikan bandeng, Bandeng Juwana berusaha menciptakan variasi produk yang luar biasa, sehingga saat ini memiliki 78 variasi produk dengan bahan utama bandeng. Variasi produk dari bahan utama yang sama ini menjadikannya Bandeng Juwana memiliki keunikan, karena pilihan yang diberikan sangat banyak yang tidak dimiliki oleh para pesaingnya. Bahkan Bandeng Juwana secara berkala juga mengadakan acara Bazar Bandeng agar produk-produk bandengnya dikenal oleh para pelanggannya.

\footnotetext{
${ }^{10}$ Wawancara dengan Arif, tanggal 13 Oktober 2018
} 
Selain itu, untuk mewujudkan keunikan tersebut, Bandeng Juwana juga membuat bermacam-macam produk yang terkenal dari berbagai daerah yang laku di pasaran dengan merk sendiri (private label) "Dyriana" berdampingan dengan berbagai produk ternama tersebut. Dengan demikian, para pelanggan mempunyai berbagai pilihan produk dengan variasi harga sesuai dengan kemampuannya. Hal inilah yang merupakan keunikan dari pusat oleh-oleh Bandeng Juwana.

\section{KEMAMPUAN DINAMIS}

\section{(DYNAMIC CAPABILITIES)}

Visi yang dicanangkan oleh Bandeng Juwana mampu menciptakan karya kreatif dan inovatif, sehingga memunculkan kemampuan dinamis bisnis ini, seperti yang diungkapkan oleh dr. Daniel berikut ini :

"Siapa saja yang mempunyai ide atau contoh, dibuat

Kasih sama kreatif (kasih dan kreatif) itu kita jalankan terus Karyawan kita itu .... pada umumnya banyak sekali yang kreatif" $" 11$

\footnotetext{
${ }^{11}$ Wawancara dengan dr. Daniel, tanggal 27 Januari 2018
}

Untuk mewujudkan kemampuan dinamis ini, Bandeng Juwana mampu memberdayakan seluruh karyawannya untuk berperan serta dalam mewujudkan kreativitas produk. Setiap ulang tahun perusahaan juga diadakan lomba kreativitas menciptakan produk baru dan diberikan hadiah. Dengan demikian kegairahan untuk senantiasa berinovasi menjadikan Bandeng Juwana memiliki kemampuan dinamis yang sesuai dengan kebutuhan pasar.

Untuk terus mempertahankan kemampuan dinamisnya, seluruh pemilik dan karyawan Bandeng Juwana berusaha mendapatkan informasi dari pembeli, baik itu pelanggan maupun konsumen yang baru membelinya. Berbagai masukan, saran, kritikan dan keluhan para pembeli tersebut ditampung untuk dipelajari dan selanjutnya untuk perbaikan. Selain itu juga berbagai pengalaman yang selama ini diperolehnya, dipergunakan untuk berubah menjadi lebih sesuai dengan kebutuhan pelanggan. Seperti yang diungkapkan oleh dr. Daniel demikian :

"Jadi kita itu berusaha untuk dekat dengan pembeli Jadi saya itu belajar dari pengalaman 
Jadi tiap kali itu kita berubah dari pengalaman",12

Ditambahkan pula oleh Arif bahwa dalam dunia bisnis oleh-olehpun harus mengikuti trend yang sedang terjadi supaya tetap sesuai dengan selera konsumen, seperti yang dituturkan demikian :

"Kreativitas dan berkualitas

Trendnya apa ..... kami mengikuti" $" 13$

\section{KEPERCAYAAN (TRUST) DAN KOMITMEN}

Visi mengandung suatu keyakinan, nilai-nilai, prinsip, dan janji yang mengikat, yang apabila diyakini dan diejawantahkan dengan sempurna, akan menciptakan faktor kepercayaan dan komitmen. Kedua faktor ini menjadi ciri khas suatu bisnis keluarga yang berhasil. dr. Daniel sangat memahami dan mewujudkan kedua faktor itu bertumbuh dengan sempurna di bisnis Bandeng Juwana. Hal ini nampak dari tindakannya yang berani

\footnotetext{
${ }^{12}$ Wawancara dengan dr. Daniel, tanggal 27 Januari 2018

${ }^{13}$ Wawancara dengan Arif, tanggal 13 Oktober 2018
}

mempercayakan bisnis keluarganya kepada menantu tertua yang bernama Arif. Berikut pernyataannya :

"Langsung saya kasikan Arif, 'Rif, kowe nyekel Rif'

Rif kamu cekel, nanti kamu rembugan sama saudara-saudara, sebulan ambil berapa

Saya ndak tahu. Lancar ok, jalan lancar. Anak dan mantu jauh lebih terbuka

Omong-omong blak-blakan",14

(Langsung saya berikan ke Arif, 'Rif, kamu pegang Rif'

Rif kamu pegang, nanti kamu bicarakan dengan saudarasaudara,

Sebulan ambil gaji berapa

Saya tidak tahu. Lancar semuanya, berjalan lancar.

Anak dan menantu jauh lebih terbuka

Komunikasi terbuka apa adanya)

Memberikan tongkat estafet bisnis pertama kali kepada menantu tertua adalah suatu langkah berani di dalam mewujudkan prinsip kepercayaan (trust). Hal itu tidak terlepas dari adanya komitmen kedua belah pihak, baik dari pemberi kepercayaan (dalam hal ini dr. Daniel) dan penerima kepercayaan (dalam hal ini Arif). Untuk mengokohkan kepercayaan dan komitmen tersebut, diadakanlah

\footnotetext{
${ }^{14}$ Wawancara dengan dr. Daniel, tanggal 27 Januari 2018
} 
pertemuan berkala (general meeting) setiap hari Selasa yang diikuti oleh semua kepala bagian, anak-anak dan menantunya, sementara dr. Daniel mendengarkan dan memberikan masukan. Arif memimpin pertemuan tersebut untuk membiarakan masalahmasalah yang dihadapi untuk dijadikan masukan demi keberhasilan bisnis Bandeng Juwana.

\section{BAGAN FAKTOR-FAKTOR YANG MEMENGARUHI KELANGENGAN BISNIS KELUARGA}

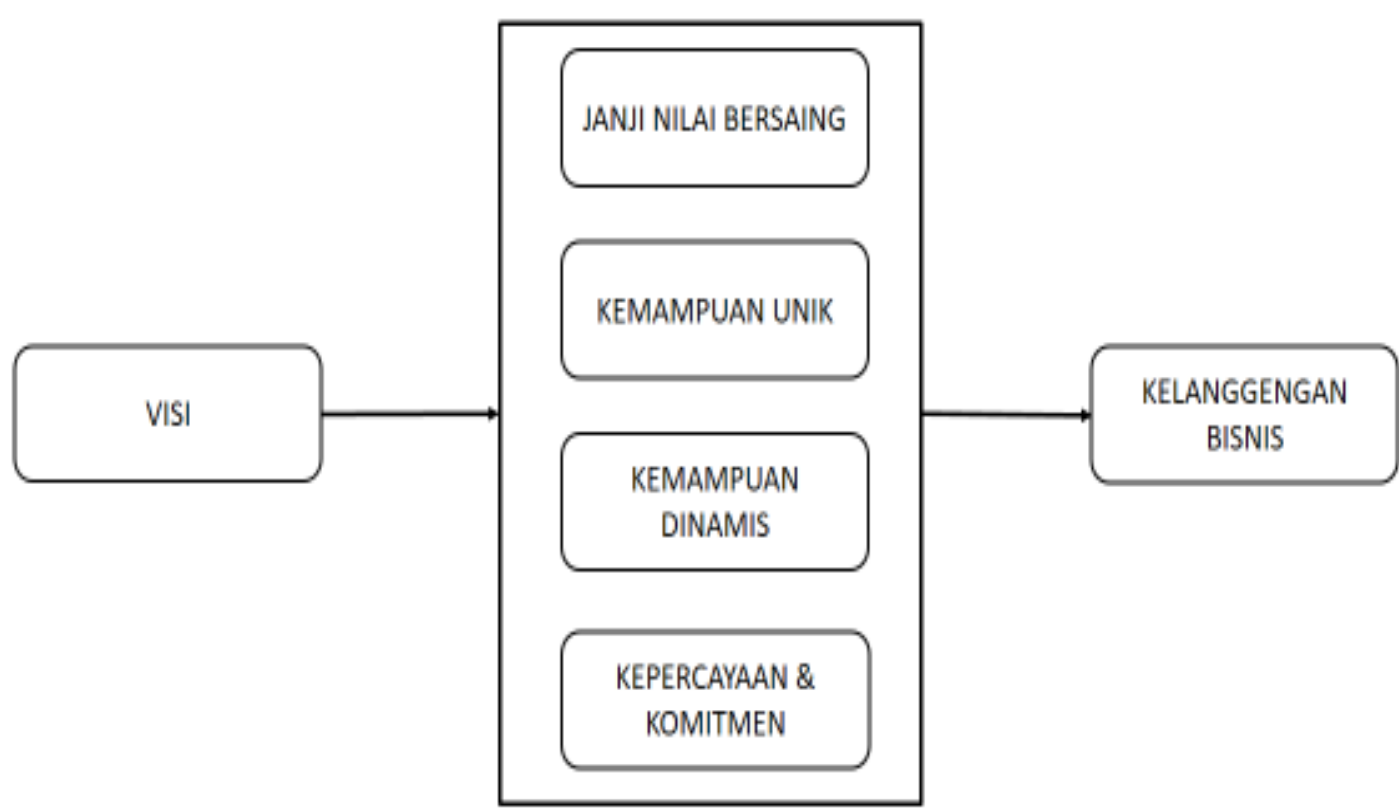

Gambar 1: Faktor-faktor yang terbentuk dari visi suatu bisnis keluarga yang memengaruhi kelanggengan bisnis Sumber : Data primer yang diolah oleh peneliti (2019)

Gambar 1 di atas adalah bagan tentang faktor-faktor apa saja yang terbentuk dari visi suatu bisnis keluarga yang memengaruhi kelanggengan bisnis, bukan sebagai model atau teori mini. Dari bagan tersebut nampak bahwa visi memengaruhi 
terbentuknya 4 faktor penting tercapainya kelanggengan bisnis, yaitu janji nilai bersaing, kemampuan unik, kemampuan dinamis, serta kepercayaan dan komitmen.

\section{KESIMPULAN}

Visi merupakan fondasi bisnis keluarga, karena di dalamnya terkandung suatu keyakinan, nilai-nilai, prinsip, dan janji yang mengikat. Visi yang diyakini oleh seluruh pemangku kepentingan dan diejawantahkan dengan tepat akan menghasilkan kekuatan untuk melanggengkan suatu bisnis keluarga. Di satu sisi, keyakinan dan pengejawantahan visi tersebut akan memuaskan konsumen, di sisi yang lain memotivasi tercapainya harmoni keluarga, toleransi terhadap perbedaan, partisipasi dan keterbukaan, agar kelanggengan bisnis keluarga tercapai.

$$
\text { Visi yang diyakini dan }
$$
diejawantahkan di dalam bisnis keluarga akan membentuk beberapa faktor yang bermanfaat di dalam persaingan, yaitu :

- Janji nilai bersaing terwujud apabila barang/jasa serta layanan yang ditawarkan mampu memberikan solusi yang lebih baik daripada pesaing.
- Kemampuan unik yang dimiliki oleh suatu bisnis memudahkan pelanggan untuk membedakannya dari pesaing. Ada ciri khas yang dimiliki bisnis tersebut yang tidak dimiliki oleh pesaingnya.

- Visi mampu memengaruhi terciptanya karya kreatif dan inovatif, sehingga memunculkan

\section{kemampuan dinamis}

- Visi mengandung suatu keyakinan, nilai-nilai, prinsip, dan janji yang mengikat, yang apabila diyakini dan diejawantahkan dengan sempurna, akan menciptakan faktor kepercayaan dan komitmen. Kedua faktor ini menjadi ciri khas suatu bisnis keluarga yang berhasil.

\section{SARAN}

Perlunya direncanakan model bisnis selanjutnya sepeninggal generasi pertama, agar apa yang telah dicapai saat ini dapat berkelanjutan dari generasi ke generasi, mengingat bisnis keluarga biasanya menghadapi tantangan yang sangat berat saat memasuki generasi ketiga.

Untuk mendapatkan gambaran yang lebih mendalam tentang Bandeng Juwana, disarankan untuk penelitian selanjutnya menggunakan metode kualitatif dengan 
desain grounded theory, agar dihasilkan teori mini yang memberikan gambaran yang lebih lengkap tentang peran visi suatu bisnis keluarga.

\section{KETERBATASAN PENELITIAN}

Berhubung adanya keterbatasan waktu, penelitian kualitatif ini dilakukan melalui wawancara mendalam hanya dengan 2 informan kunci. Oleh karena itu, peneliti melengkapinya dengan melakukan observasi di berbagai waktu yang berbeda, serta studi dokumentasi dari situs terkait di internet.

\section{DAFTAR PUSTAKA}

Barney, Jay. 1991. Firm Resources and Sustained Competitive Advantage. Journal of Management. Vol. 17, No. 1, p. $99-120$

Carlock, Randel S. dan John L. Ward. 2001. Strategic Planning for the Family Business. first edition. Palgrave Macmillan, New York

Carpenter, MA dan Wm. Gerard Sanders. 2009. Strategic Management $-A$ Dynamic Perspective Concepts and Cases. Second Edition. Pearson Prentice Hall, New Jersey.
Conte, Francesca, Siano, Alfonso, dan Vollero, Agostino. 2017. CEO communication: engagement, longevity and founder centrality. An exploratory study in Italy. Corporate Communications: An International Journal

Creswell, John W., terjemahan. 2015. Penelitian Kualitatif \& Desain RisetMemilih di Antara Lima Pendekatan. Cetakan 1.

De Wit, Bob dan Ron Meyer. 2005. Strategy Synthesis : Resolving Strategy Paradoxes to Create Competitive Advantage (Text and Readings). Second edition. Thomson Learning. London.

Ghony, M. Djunaidi dan Fauzan Almanshur. 2012. Metodologi Penelitian Kualitatif. Cetakan I. ArRuzz-Media. Jogjakarta.

Grote, Jim. 2003. Conflicting Generations : A New Theory of Family Business Rivalry. Family Business Review. vol. XVI. no. 2, p. 113-124

Heryjanto, Andreas. 2016. Disertasi : Mitosis-bisnis, Strategi Generasi Ketiga Lunpia Semarang Mempertahankan Keberlanjutanbisnis. FEB Universitas Kristen Satya Wacana, Salatiga.

Hooley, Graham, Nigel F. Piercy dan Brigitte Nicoulaud. 2012. Marketing Strategy \& Competitive Positioning. fifth edition. Pearson Education Limited, England.

Ihalauw, John JOI. 2013. Family-Business Enterprise - Regular \& International Program. Power point slides 
Lee, Jim. 2004. The Effect of Family Ownership and Management on Firm Performance. SAM Advanced Management Journal. p. 46-53

Morden, Tony. 1997. Leadership as vision. Management Decision, Vol. 35 Iss 9 pp. $668-676$

Susanto, AB et. al. 2007. The Jakarta Consulting Group on Family Business. Divisi Penerbitan The Jakarta Consulting Group, Cetakan I.

Ta`pies, Josep dan Moya, Mar1'a Ferna'ndez. 2012. Values and longevity in family business: evidence from a cross-cultural analysis. Journal of Family Business Management Vol. 2 No. 2, pp. 130-146

Tokarczyk, John et. al. 2007. A ResourceBased View and Market Orientation Theory Examination of The Role of 'Familiness' in Family Business Success". Family Business Review vol. $\mathrm{XX}(1): 17-31$
Ward, John L. 2004. Perpetuating the Family Business (50 Lessons Learned from Long-Lasting, Successful Families in Business). first edition. Palgrave Macmillan, Hampshire

Wernerfelt, Birger. 1984. A Resourcebased View of The Firm. Strategic Management Journal vol. 5:171-180

Yoeli, Raya dan Berkovich, Izhak. 2010. From personal ethos to organizational vision: narratives of visionary educational leaders. Journal of Educational Administration Vol. 48 No. 4, 2010 pp. 451-467

\section{https://www.bandengjuwana.com/,} diunduh per 2 Maret 2018

Jateng.tribunnews.com/.../kisah-suksesdokter-daniel-nugroho-bisnisbandeng-presto, diunduh per 2 Maret 2018 